\title{
Beginning with the Self to Critique the Social: Critical Researchers as Whole Beings
}

\author{
Nancy Taber \\ Brock University \\ Canada
}

\section{Introduction}

In this chapter, I argue for the importance of problematizing researcher subjectivity using an analytic autoethnographic lens in critical social research, from a feminist perspective. The aim is not to use autoethnography as a methodology per se, but to use autoethnography as a theory and a method as an (iterative) starting point to interrogate social ruling relations. In much the same way that Dorothy Smith (2005) explains that institutional ethnography is not only a methodology but is a "sociology for people" (p. 220), I view autoethnography as a lens through which researchers can connect their own everyday lives to the various contexts of their research in order to engage in a societal critique.

To do this, I begin the chapter with a brief introduction of my own positionality in relation to my argument (a brief autoethnography). This chapter is centred on my own experiences, connecting my personal life with my ongoing scholarly journey, leading me to address the question, Am I am feminist anti-militarist (Enloe, 2000, 2007; Feinman, 2000) or do I use feminist antimilitarist theories? In so doing, I explore how my research is very much connected to who I am, not only as a scholar, but in other contexts of my life. In other words, I do not simply utilize theories, but I live them.

Next, I draw on the work of bell hooks (1994) to explore academics as whole beings with bodies, emotions, and lives outside academia, not as decontextualized disembodied minds confined to research. In my argument, I also discuss researchers from various disciplines who explicitly examine how their own selves (i.e., who they are themselves as humans as well as how they appear to others) directly affect their research itself (Ellingson, 2006; Reich, 2003; Woodward, 2008).

Then, I discuss the main tenets of autoethnography (Anderson, 2006; Reed-Danahay, 1997a, $1997 b, 2002)$ leading to an exploration of how it can be used to frame other methodologies conceptually, theoretically, and empirically (i.e. as a theory and a method). I delineate how an examination of embodiment, subjectivity, and researcher positionality through autoethnographic methods can be an entry point into critical social research, but should not be the end point.

Finally, building on Smith's $(1987,1999,2005)$ work on institutional ethnography, I discuss how, in critical social research, the aim is to explore ruling relations with the purpose of 
critiquing systemic structures. Due to intersecting oppressions, while it is often not possible to delineate people categorically into the oppressed and the oppressors (as Freire, 2000 might argue), it is nonetheless important to explore how systems (as created, maintained, and altered by humans) serve to marginalize and oppress certain groups of people (as well as non-human animals and the earth itself) while privileging others. By beginning with the self, I argue, researchers can better explore their own positionality in order to critique the social.

\section{My own journey as a researcher}

I came to academia through a rather circuitous route. Indeed, having a career as a scholar had never entered my mind when I was younger. As a teenager, I wanted to have an exciting life that was nontraditional for a woman, so I decided to join the Canadian military. I went to military college for my undergraduate degree, trained as an air navigator, and deployed on Canadian destroyers and warships as a Sea King helicopter Tactical Coordinator (TACCO). I loved my life in this "masculine" role, disregarding the ways in which my being a woman often worked to my detriment. However, I gradually became further and further dissatisfied with militarized masculine ways of knowing and acting, eventually deciding to leave the military after getting married and having a child. During my last few years of service, while on a ground tour (after deploying operationally), I had also become increasingly involved with military Workplace Relations (WR), facilitating anti-harassment seminars and participating in the mediation of disagreements that fell under the parameters of WR. Knowing I would need some other form of education to help me successfully switch careers, I took my Master of Education (MEd) degree, originally intending to participate in military WR as a Reserve Officer or as a civilian.

Eventually, I came to realize that, although WR policies were intended to increase tolerance and decrease harassment, they could only do so much. My MEd helped me to see the world in different ways, as I read work by critical and feminist scholars, and I began to question my experiences in the military, starting to see them from a political perspective, not just a personal one. I became enthralled with the ability of theory to illuminate my understandings of the world (see Taber, 2005, for an exploration of how my MEd led me to consciously and critically question my place in the military). I began to acknowledge that "the importance of our everyday experiences cannot be ignored, and are a rich source of data when approached with an integration of theory and reflexivity" (Taber, 2005, p. 290). My personal story is unique to me and does not speak for others. However, "my narrative is important to reveal the complexities of being a woman in the CF [Canadian Forces], and to connect women's experiences with organizational ruling relations and societal influences. We cannot afford to separate theory and research from the daily experiences of women" (Taber, 2005, p. 299).

My article about my gendered learnings in the military has led to my understanding that, in an organization that valued heteronormative militarized masculinity, women and those designated as "other" are only likely to be tolerated, not accepted in any sense of the word. As I have more recently written in reference to my research with military mothers (Taber, 2011c), policies intended to recruit and retain women members are "a safe way for militaries 
to appear gender-equitable at the same time as they are able to protect the militarized hegemonic masculinity that characterizes their organizational cultures" (p. 345). There appears to be no intention of changing military culture, just making designated groups fit the system better. However, at the time that I left the military, my understandings of these complex dynamics were just beginning to emerge. It was in doing further reading and research that I was able to problematize the connections between my own experiences and the military organizational context.

After my MEd, I did some consulting work in the field of career development and taught a non-credit post-secondary student success course. I then began teaching courses with my MEd alma mater as a Lecturer. In so doing, I realized that I wanted a career in academia. Over the next several years, I took my PhD in Education, taught in a limited term appointment (LTA), and attained a tenure-track position. Originally, while working on my $\mathrm{PhD}$, I did not want to explore anything even remotely related to my military experiences. I eventually came to realize that it was precisely those military experiences that needed to be problematized, centering my dissertation (Taber, 2007; also, Taber, 2011b in book format) on them. I used autoethnography as an entry point into an institutional ethnography of the military (see Taber, 2010 for an extended discussion of my methodology, as well as below), exploring how my experiences connected to military policies and texts, as well as to books written for the children of military members.

Instead of separating from the military, as I once thought I would do, my research program extends from it. As I wrote in my dissertation:

I made a decision to ground my research from my own standpoint in the everyday as a woman, a former mother in the military, and as an academic whose work increasingly draws upon notions of social justice and care, using autoethnography and access to military information in the public domain. It is this often contradictory standpoint [as a former military member critiquing the military] (which I do not aim to resolve) that grounds my research, and is useful as it allows me to explore the military from both 'insider' and 'outsider' perspectives (Taber, 2007, pp. 50-51).

In retrospect, it was rather naïve to think that there was a before, during, and after to my military life, each neatly detached from the others, with one aspect of my life never informing another one. By embracing my own personal history instead of separating from it, I have built a research program focusing on militarism, gender, and learning, extending my military analysis from my experiences and the military institution itself to the experiences of other military mothers, everyday life, popular culture, and children's literature.

In telling my story, I aim to demonstrate that I am not an objective, unbiased researcher who is disconnected from her focus of study, nor do I want to be. My personal history, experiences, and subjectivity strengthen my research; they do not detract from it. "My understandings of military life, combined with my feminist academic background, make me unique as a researcher focusing on the organizational policies and practices of the military" (Taber, 2010, p. 12). By acknowledging that I am not disconnected from my research, I can better position myself as a whole being; various aspects of my life are not dichotomized but are interconnected. I do not simply use theory and methodology in my research, I live it. 
The question of how theory is embedded in my life came up in conversation with a colleague several years ago. I was describing how, in introducing myself in the first session of one of my courses, I had explained that I am a feminist antimilitarist. My colleague asked why I had used that specific framing of myself. Why had I not, he asked, simply stated that I used feminist antimilitarist theory? The question was an illuminating one, prompting me to think of my own positionality as a scholar. Why indeed had I employed that specific wording? Am I a feminist antimilitarist or do I use feminist antimilitarist theory?

Feminist antimilitarism critiques "armed force as a way of politics....[and engages in a] complex analysis of militarism...to destabilize notions of gendered armed forces...to account for the economic and environmental repercussions of maintaining a militarized government, and to separate martial service from first-class citizenship rights" (Feinman, 2000, p. 212). It explores how "military needs and militaristic presumptions [are seen] to be not only valuable but also normal.... [Militarism] involves cultural as well as institutional, ideological, and economic transformation" (Enloe, 2000, p. 3). In specifically addressing how gender and women are wrapped up with militarism, Enloe argues that:

Militaries rely on women, but not all women experience militarization identically. Militaries have needed, and continue to need, some women to provide commercialized sexual services to male soldiers, other women to commit themselves to marital fidelity in military families; simultaneously, they need still other women to find economic security and maybe even pride in working for defense contractors. At times governments even need some civilian women to act as feminist lobbyists promoting women's right to serve in the state's military (Enloe, 2000, p. xii).

It is this complex web of somewhat contradictory relations that has captured my personal and academic interest, bound up in my personal experiences, scholarly research, and professional identity. I believe that my research informs my life and my life informs my research. I do not so much use feminist antimilitarist theories as I live and breathe them. The ways in which I view the world, in my everyday life outside academia, are very similar to the ways in which I view it in academia. When I interact with my family and friends, with my community, with news media and popular culture, feminist antimilitarist theories inform my understandings, words, and actions. In other words, my life as a scholar is very much connected to my life as a citizen, community member, mother, partner,... I do not claim a harmonic identity without contradiction or complication (and certainly there are various understandings of feminist antimilitarism), but that I have recognized that I am a whole being who cannot separate one aspect of her life from another. Upon reflection, I realized that the wording I originally used was extremely apt. I can claim that I am a feminist antimilitarist.

\section{Subjectivity, researcher positionality, and whole beings}

How (or even if) a researcher locates her/himself in research depends on the focus of specific research projects and the various research methodologies that could be utilized. For instance, ethnographies, case studies, grounded theory, narrative, and phenomenology focus on participant cultures, experiences, stories, and understandings (Creswell, 2006). In each case, a researcher may or may not choose to explore her/his own positionality, 
although with narrative, it is common for researchers to share their own stories (Clandinin \& Connelly, 2000; Cole \& Knowles, 2001) and in autoethnography, researchers' stories themselves are the focus.

In general, much of qualitative research does entail researcher reflexivity on her/his own subjectivity and how she/he is positioned with respect to her/his research. However, although "most qualitative researchers are reflexive...they do not publish their reflections.... To many researchers, it seems safer to leave some issues unspoken and unwritten" (Possick, 2009, p. 861). Publishing reflections can leave researchers feeling vulnerable and "may lead to criticism by colleagues that the researcher is too subjective" (p. 861).

Nonetheless, many researchers are overtly reflective, acknowledging that they are not objective outsiders but are intricately connected to the contexts and participants of their research. In fact, as Woodward (2008) states:

the insider/outsider dichotomy and that between objectivity and subjectivity... are based on far too crude a polarization. The research process can never be totally 'inside' or completely 'outside', but involves an interrogation of situatedness and how 'being inside' relates to lived bodies and their practices and experiences (Woodward, 2008, p. 547).

Researchers' lived bodies come not only with minds (which are often privileged above all else in academia) but with spirits, emotions, and whole lives. hooks (1994) argues that "the task for those of us who chose this vocation [of academia] was to be holistically questing for self-actualization" (p. 16). She states that, unfortunately, "The idea of the intellectual questing for a union of mind, body, and spirit had been replaced with notions that being smart meant that one was inherently emotionally unstable and that the best in oneself emerged in one's academic work" (p. 16). This disconnection between the lived experiences of academics and their scholarship as teachers and researchers is a result of "a mind/body split, one that promotes and supports compartmentalization" (p. 160).

It is impossible to work as holistic beings when "what counts" in academia is measured solely by the scholarly work of disembodied minds. Yet it can be difficult to bring selves into research, particularly when much of academia frowns on it, even in qualitative research. hooks (1994) states that "most professors must practice being vulnerable in the classroom, being wholly present in mind, body, and spirit" (p. 21). I would argue that this is equally true for researchers. To bring in one's own story to academic work can be an uncomfortable exercise in vulnerability. Yet one's subjectivity, embodiment, and experiences always affect research, whether it is recognized or not.

An interesting example of a researcher who recognized how her embodied self was intricately connected with her work is Reich's (2003) account of the ways in which her pregnant body interacted with her research in child protection. While she at first tried to hide and then downplay her pregnancy, she eventually embraced it as a researcher.

Realizing I could no longer avoid it, I surrendered to the assigned role of pregnant person, and began to observe the expectations of that role. I was surprised to find that my own pregnancy was an important source of data, both in terms of more viscerally understanding the experience of the public gaze pregnancy and children elicit and in terms of the unique information it yielded (Reich, 2003, p. 356). 
Feminist research, although as diverse as the various forms of feminism (Ramazanoglu \& Holland, 2002), has main tenets that support researcher reflexivity. It contests the argument that "the voice of science is a masculine one" (Harding, 1986, p. 3) from a positionless objective standpoint (Smith, 1999). "Defining what is in need of scientific explanation only from the perspective of bourgeois, white men's experiences leads to partial and even perverse understandings of social life. ...feminist research...generates its problematics from the perspective of women's experiences" (Harding, 1986, p. 7). By acknowledging academics as whole beings, we can resolve the "bifurcation" that often exists between the world scholars experience in academia and in everyday life (Smith, 1986). "The only way of knowing a socially constructed world is knowing it from within. We can never stand outside it" (Smith, 1986, p. 92). Feminism not only places gendered social relations at the centre of analysis, which is an achievement in itself, but "it insists that the inquirer her/himself be placed in the same critical plane as the overt subject matter, thereby recovering the entire research process for scrutiny" (Harding, 1986, p. 9). The researcher cannot be detached from the research.

In my own research, although I have often highlighted an exploration of my own subjectivity (i.e. Taber, 2005, 2007, 2011a), I have also unconsciously sidelined it. For instance, in conducting a collaborative narrative inquiry on the experiences of adult educators, my co-researchers and I gradually came to an understanding that, in an effort to be collaboratively open-minded, we had unintentionally disregarded our own conceptual and theoretical understandings, only to have them resurface through our data analysis (Taber, Howard, \& Watson, 2010).

In our original attempts to engage in a collaborative process with each other as researchers, we consciously focused on how to work well together while unconsciously sidelining issues of our own subjectivities and analytical frameworks. When we began to consciously acknowledge our own perspectives, both individually and collectively, we were able to view the data in a different light (Taber, Howard, \& Watson, 2010, p. 41).

By collaboratively acknowledging who we were as scholars, we were better able to reflexively analyze each of our own interactions with the data and the research. We argued that, as researchers, there are "unique ways in which we bring our personal selves to our research process.... We wear lenses from our own lived experiences that inform us...we must be diligent in our practice of reflexive inquiry" (p. 45). Subjectivity "is a powerful yet too often unacknowledged and unexplored tool" (Taber, Howard, \& Watson, 2010, p.41) for understanding research, participants, and researchers themselves. We therefore explored how, "by locating our presence within the inquiry process in a more intentional manner, we were able not only to attend to our participants' stories, but to forefront how our own various perspectives informed our findings" (p. 46). In other words, we were better able to explore how who we are continually interacts with how we research.

In a separate collaborative research project that led to conducting a girl empowerment book club for struggling readers (through a sociological case study), our research stance was much more delineated from the beginning. In fact, another faculty member and I had decided to work together based on our differing interests (mine on gender and hers on learning exceptionalities). As we proceeded with our research, a graduate student also 
began to work with us, moving from her position as a research assistant to a collaborative research partner. What became interesting for us methodologically was how we began to interact with our participants, attempting to balance the tensions in our roles as researchers, observers, and facilitators for girl empowerment (Lane, Taber, \& Woloshyn, in progress), which were intricately connected to who we were professionally and personally. One aspect of our work explored how, at various stages in our careers, we have different professional concerns and personal situations, as well as varying scholarly foci, each of which affected our research.

While one of us was a full professor who was formally secure in her university position but is in an ongoing search for ways to engage in meaningful research, one of us was applying for tenure at the time of the research, with the other completing her Master's degree and applying for a PhD program. As such, we were feeling differential pressures to complete our research in order to publish it in peer-reviewed journal articles. Feminist research can be challenging as universities typically value forms of academic commitment and productivity that 'are generally defined within a masculine marketplace framework' (Gouthro, 2002, p. 8). Universities are becoming ever more corporatized (Reimer, 2004; Webber, 2008) leading to the "commercialization of all aspects of university life" (Hornosty, 2004, p. 47) wherein "the primary danger...is the subtle intrusion of a corporate ideology, which works to redefine the university's priorities" (p. 48). This corporate ideology often gives "priority to entrepreneurial-type research" (p. 54) which "undermine[s] feminist research...which would carry little weight in tenure and promotion considerations" (pp. 54, 55). Although our focus on girl empowerment never wavered, we were conscious of the ways in which the academic context in which we work interacted with our research as well as with our plans for publication. Ignoring this context, and how our subjectivity as researchers and academics affected the research process, would have been to negate significant influences on our work. At the same time as we were dedicated to our participants and our research aims, we were conscious of the need to publish in order to move up the academic ranks.

I argue that, regardless of methodology used, it is always appropriate to examine researchers' subjectivities through an autoethnographic lens. I have conducted various research projects, as described above, that drew on the different methodologies of institutional ethnography (with an autoethnographical entry point), narrative inquiry, and sociological case study. In each of these examples, a critical examination of researcher subjectivity and positionality became integral to the research process. Ramazanoglu and Holland (2002) state, "if you want direct contact with research subjects, it may be useful to reflect on your own experiences and to clarify your taken for granted assumptions where these could be relevant" (p. 155). I extend this statement to encompass any research, including that which does not use human participants. The positionality of researchers is an inherent part of research, whether acknowledged or not. Although many researchers do explore their subjectivity, this exploration should be extended to allow for an appreciation and acceptance of researchers as whole beings who are central to their own research.

\section{Autoethnography: Connecting the self to the social}

Autoethnography is a research methodology that places the researcher in the research as a participant, with varying emphases on the self and the social (Reed-Danahay, 1997a). 
Ellingson's (2006) work points to the ways in which autoethnography can "(potentially) offer embodied details, celebrate the author's position, problematize the production of knowledge, and reveal the profane [i.e. the body] in the sacred processes of research" ( $p$. 304). Autoethnography makes the researcher central to the research process, refusing to view researchers as disconnected in any way from their research. However, autoethnographers disagree on the specific position that a researcher's self should take in relation to the social.

A useful definition from Reed-Danahay (1997a) describes autoethnography as "referring either to the ethnography of one's own group or to autobiographical writing that has ethnographic interest. Thus, either a self (auto) ethnography or an autobiographical (auto) ethnography can be signalled by "autoethnography" (1997b, p. 2). She views these two types as not discrete but connected, with autoethnographic researchers exploring self within a larger ethnographic context.

While certain scholars would argue that a research focus on the self should be privileged without an overt sociocultural critique, where making meaning is left to the reader, termed evocative autoethnographies (Ellis \& Bochner, 2000; Ellis, 2002, 2004), others argue that the self should be used as an entry point only, enabling an exploration of experiences that leads to a sociocultural analysis, termed analytic autoethnographies (Anderson, 2006; Atkinson, 2006; Atkinson \& Delamont, 2006). I subscribe to the latter argument, wherein the research aim is not to explore oneself per se, but to engage in a sociocultural critique by beginning in one's everyday experiences (Taber, 2005, 2007, 2010, 2011a), exploring how and why we as researchers come to focus on specific concepts, theories, questions, and methodologies.

Atkinson and Delamont (2006) welcome the introduction of stories into qualitative research at the same time as they bemoan the ways in which they are often accepted at face value. They contend that a critical analysis of any data, in particular that which arises from personal experience stories, is crucial. Stories should not stand on their own but should be interrogated in order to engage in a social critique.

When it comes to personal narratives, spoken performances, oral testimony and autoethnographies, we should not simply collect them as if they were untrammelled, unmediated representations of social realities. While the development and spread of qualitative social science are to be welcomed, too many of its manifestations result in slack social science, born of an adherence to the evocation of 'experience', as opposed to the systematic analysis of social action and cultural forms. It is, we suggest, a vital corrective that narrative should be viewed as a form of social action, with its indigenous, socially shared, forms of organization. Narratives should be analyzed as a social phenomenon, not as the vehicle for personal or private experience (Atkinson \& Delamont, 2006, p. 170).

When "narrative [is]...viewed as a form of social action," it can become a vital starting point for critical social research. Walford (2004) similarly argues that researchers "learn about the general from the particular" (p. 413), which necessarily means that we cannot stay with the particular alone. Personal stories should be a starting point (and iterative touchstone) that allows researchers to link the self to the social. 
More recently, Reed-Danahay herself (2009) argues for critical autoethnography, stating:

Autoethnography is not the kind of autobiography in which the author as hero or heroine is neither constrained nor assisted in life by economic, social, or cultural position; autoethnography is also not a form of writing ethnography that erases the anthropologist and his or her encounters with research participants. It is a form of writing, a method for life writing and for social analysis, which depends upon an ethnographer's capacities for observation and sensibilities of empathy, reflexivity, and critique. Autoethnography falls squarely at the intersection of insider and outsider perspectives, and thereby encourages us to explore more fully the implications and, perhaps, misguided uses of this dualism (p. 43, italics added).

It is precisely the "method for life writing and for social analysis" for which I am arguing. In all forms of research, researchers should connect who they are with what and who they research. As Reed-Danahay (1997b) states, "The notion of autoethnography foregrounds the multiple nature of selfhood and opens up new ways of writing about social life" (p. 3). When researchers connect their own lives to their research, they do not explore decontextualized phenomena to which they are disinterested, but explore meaningful issues in which they are intricately invested. Motzafi-Haller (1997), who conducted an autoethnography of her insider/outsider research as a Mizrahi (minority) Jew in Israel, describes her connection to her work as follows: "The questions I dealt with were not abstract issues of social justice but pertinent to my daily existence" (p. 202).

An autoethnographic lens should therefore start with the self in order to the critique the social. There is a "dual nature of social research: that it depends both on some connection with that being researched and on some degree of separation from it" (Davies, 1999, p. 10). Therefore, researchers should consider "how does who I am, who I have been, who I think I am, and how I feel affect data collection and analysis"? (Pillow, 2003, p. 176).Yet, this begs the questions, "how much autobiography is too much? How much is not enough? Disclosing ourselves in our research is risky, and, at the same time, frightening" (LePage \& Givens-Generett, 2003, p. 26). This risk points to the importance of "foreground[ing]" (Possick, 2009, p. 861) researcher reflections due to the ways in which "emotional experiences...aid understanding and raise significant unanticipated insights (Lankshear, 2000)" (Possick, 2009, p. 861).

Unfortunately, "certain discourses, such as disembodied, abstract theories, have a high status in our Western society; [and] others, the embodied [and emotional] ones, have less prestige and often gain less hearing" (Abma, 2002, p. 7). There is a "myth of the positionless speaker as the one who speaks the most valuable truths....'Masculinity' and 'science' gain much of their status through their claim to positionless 'truth'; that is, a truth that, no matter who one is or where one stands, would still be the same" (Davies, 1992, p. 54). Smith (1986, 1987, 1999, 2005) also argues that there is no such thing as a positionless speaker. Any claim to be thoroughly objective is false. All research and all researchers come from somewhere, with their own histories, perspectives, and understandings.

By using autoethnography as a research lens, researchers can acknowledge the ways in which they are connected to their research and use these connections as valid and validated entry points into their work, as well as touchstones throughout the research process. This approach treats researchers as holistic beings with bodies, minds, and spirits, not disembodied decontextualized positionless minds. It is important therefore to not only have 
a methodological understanding of autoethnography, but a conceptual one as well. While there may not be a place for a full autoethnography in every research project, there is certainly a place for an autoethnographic lens that explores the researcher's subjectivity and positionality as a whole being in relation to research.

\section{Critical social research: Using institutional ethnography as a sociology}

Smith's (1999) work points to the importance of starting research from the everyday lives of women, as researchers and participants. Researchers need to work from the bottom-up, beginning with the localized concrete realities of people's lives, not from grand theory that proposes an overarching generalized view of universal knowledge. She argues that:

The standpoint of women....begins one step back before the Cartesian shift that forgets the body. The body isn't forgotten; hence, the actual local site of the body isn't forgotten. Inquiry starts with the knower who is actually located; she is active; she is at work; she is connected up with particular other people in various ways; she thinks, eats, sleeps, laughs, desires, sorrows, sings, curses, loves....Activities, feelings, and experiences hook her into extended social relations, linking her activities to others and in ways beyond her knowing (Smith, 1999, pp. 4, 5).

Although Smith's focus is largely on starting with participant experiences, not researcher ones, she does discuss the need for researchers to start with a problematic that emerges from their own lives (Smith, 2005). In so doing, not only would the research be personally meaningful but would give the researcher an inside perspective from which to begin. I argue for a continuation of this line of thinking in order to allow for the problematization of the researcher's connection to the research as central to the analysis. Inquiry would start with the researcher as knower and progress to participants as knowers, leading to a critical sociocultural analysis. Researcher and participant experiences and understandings would be used to not only explore an issue/context, but to engage in social critique by exploring wider power relations. Furthermore, although researcher positionality is a beginning point and significant aspect of the research, the research inquiry must broaden out from the researcher, moving to other empirical data (whether it be texts, artifacts, interviews with participants, observations, or a combination of various possibilities) in order to gain a social perspective of the wider implications of the study. In other words, it is not enough to engage in an evocative representation of experiences and understandings; an analytic critical examination that focuses on power relations is key in order to work against systemic societal marginalization and oppression.

Additionally, there are multiple oppressions (i.e., gender, race, class, heteronormativity, ableism,...) that intersect with each other in various and complex ways. People are active agents who have the ability to change their lives, but they have differential access to systems of power, leaving some more able to influence structural ruling relations than others. It is these ruling relations that need to be problematized from the standpoint of the actuality of people's everyday lives.

Smith advanced a methodology, institutional ethnography (IE), that:

is designed to create an alternative to the objectified subject of knowledge of established social scientific discourse. The latter conforms to and is integrated with that I have come 
to call the 'ruling relations' - that extraordinary yet ordinary complex of relations that are textually mediated, that connect us across space and time and organize our everyday lives - the corporations, government bureaucracies, academic and professional discourses, mass media, and the complex of relations that interconnect them (Smith, 2005, p. 11).

IE takes a subjective stance by recognizing the importance of unique individual experiences while connecting them to societal ruling relations to which most people do not have direct access. "The movement of research is from a woman's account of her everyday experience to exploring from that perspective the generalizing and generalized relations in which each individual's everyday world is embedded" (Smith, 1987, p. 185, italics in original). IE "works from the actualities of people's everyday lives and experience to discover the social as it extends beyond the experience. A standpoint in people's everyday lives is integral" (Smith, 2005, p. 10).

Briefly, IE begins with entry level data from the actualities of people's everyday experiences, typically through interviewing participants (Campbell \& Gregor, 2002) but sometimes through observations (Diamond, 2006), textual analysis (Kinsman, 1995; Walker, 1995), or researcher's own lives (Taber, 2007, 2010). These experiences are then analyzed through thematic coding that does not reduce their experiences to codes but searches for illuminating themes that help explain their standpoints (Smith, 1987). The "analysis of entry level data leads the institutional ethnographer to second level data (Campbell \& Gregor, 2002), such as texts and policies and/or interviews with policy makers, to explore how participants' lives are socially organized" (Taber, 2010, p. 11). As DeVault and McCoy (2002) state, "the key is to ask, 'How is it that these people are saying what they are saying'... the methodology allows you to go back to a political-economic context for the answer" (p. 769).

Furthermore, IE is not just a methodology but a sociology (Smith, 2005); it is not just a way of framing research but a way of understanding the world. It is an "alternative sociology" (p. 7) that "takes the everyday world as an unfinished arena of discovery in which the lines of social relations are present to be explored beyond it" (p. 39). The methodological description above can be applied sociologically by grounding research in everyday experiences in order to engage in a critique of ruling relations. Data (whether interviews, observations, texts, or researcher experiences) is not reduced to common codes but expanded to emerging themes that connect to a societal analysis of power. In my research, I have found this line of thinking to be very helpful in critiquing the ways in which women's everyday lives are bound up in structural institutions, whether the institution is a reified abstract concept such as family or a concrete organization such as a military. By beginning with researcher and participant experiences, one can explore the ways in which societal ruling relations are implicated in their lives.

In my dissertation (Taber, 2007), I methodologically adapted IE to include autoethnography and narrative (see also Taber, 2010). Doing so fit my unique research context and situation and is not necessarily relevant to all IE's. However, what may be relevant to various forms of research is the ways in which I consciously and specifically explored my own subjective experiences and understandings. Correspondingly, I have been considering how, by combining autoethnography as a lens with institutional ethnography as a sociology, researchers can approach any methodology in a reflexive, critical way. 
If, as Smith (1987) states:

the ways in which we think about ourselves and one another and about our society - our images of how we should look, our homes, our lives, even our inner worlds - are given shape and distributed by the specialized work of people in universities and schools, in television, radio and newspapers, in advertising agencies, in book publishing and other organizations forming the 'ideological apparatuses' of the society (p. 17),

then the ways in which we think about research are equally affected. Academia is a societal institution that operates as an ideological apparatus, defining how research is understood, conducted, and disseminated. As researchers, therefore, "the ways in which we think about ourselves and one another and about our society" (Smith, 1987, p. 17) must be problematized as they are intricately connected to the research that academics conduct.

\section{Conclusion}

In keeping with my argument that researchers must explore their own subjectivity and reflexivity, this chapter has focused on my own understandings and experiences. As I review my work so far, I see an ever-present theme, which has often snuck up on me in somewhat unexpected ways, about researcher positionality. What is central in this theme is the ways in which my research is implicated in my life. For me, my research is not about "abstract issues of social justice but [it is] pertinent to my daily existence" (Motzafi-Haller, 1997, p. 202). This connection is likely what draws me to methodologies such as autoethnography and institutional ethnography, although I often use other methodologies as well, depending on my research question and context (for instance, case study, life history, and feminist discourse analysis). However, even when using other methodologies, core aspects of autoethnography and IE remain with me, highlighting how they are not only methodologies but are lenses and sociologies; they are understandings that have become underpinnings in much of my work.

Academics are whole beings, not disembodied minds (hooks, 1994; Reich, 2003; Woodward, 2008), who often care deeply about their work. There should be no "bifurcation" (Smith, 1986) between academia and everyday life. Despite the vulnerability that can arise when acknowledging the ways in which we are implicated in our own research (LePage \& GivensGenerett, 2003), it is important to be consciously and overtly reflexive (Possick, 2009), exploring how the self is connected to the social (Anderson, 2006; Reed-Danahay, 1997a, $1997 b$, 2002), with respect to researchers as well as participants. "Narrative should be viewed as a form of social action" (Atkinson \& Delamont, 2006, p. 170) wherein there is a recognition that knowledge is socially organized (Smith, 1987, 1999, 2005). Stories and experiences necessitate a social analysis that connects the researcher to the research, the everyday to structural ruling relations, regardless of methodology. This does not mean that researchers' stories should dominate research, but should be acknowledged as an intricate part of it. My hope is that, by telling my story, I can assist others in exploring their own.

\section{References}

Abma, T. (2002). Emerging narrative forms of knowledge representation in the health sciences: Two texts in a postmodern context. Qualitative Health Research, Vol. 12, No. 1, pp. 5-27. ISSN 10497323 
Anderson, L. (2006). Analytic autoethnography. Journal of Contemporary Ethnography, Vol. 35, No. 4, pp. 373-395. ISSN 08912416

Atkinson, P. (2006). Rescuing autoethnography. Journal of Contemporary Ethnography, Vol. 35, No. 4, pp. 400-404. ISSN 08912416

Atkinson, P., \& Delamont, S. (2006). Rescuing narrative from qualitative research. Narrative Inquiry, Vol. 16, No. 1, pp. 164-172. ISSN 13876740

Campbell, M., \& Gregor, F. (2002). Mapping social relations: A primer in doing institutional ethnography, Garamond Press, ISBN 1-44260-119-2, Aurora, Ontario

Cole, A. L., \& Knowles, J. G. (2001). Lives in context: The art of life history research, AltaMira Press, ISBN 0-7591-0144-2, Walnut Creek

Clandinin, D. J., \& Connelly, F. M. (2000). Narrative inquiry: Experience and story in qualitative research, Jossey-Bass Publishers, ISBN 0787943439, San Francisco

Creswell, J. W. (2006). Qualitative inquiry and research design: Choosing among five approaches, Sage Publications, ISBN 0761901442, Thousand Oaks

Davies, B. (1992). Women's subjectivity and feminist stories. In: Investigating subjectivity: Research on lived experience, C. Ellis \& M. Flaherty (Eds), pp. 53-76. Sage Publications, Inc., ISBN 0-8039-4496-9, Newbury Park, California

Davies, C. (1999). Reflexive ethnography: A guide to researching selves and others, Routledge, ISBN 0415409018, London

DeVault, M., \& McCoy, L. (2002). Institutional ethnography: Using interviews to investigate ruling relations. In: Handbook of interview research: Context $\mathcal{E}$ method, J. Gubrium \& J. Holstein (Eds), pp. 751-776, Sage Publications, Inc., ISBN 0-7619-1951-1, Thousand Oaks

Diamond, T. (2006). "Where did you get the fur coat, Fern?" Participant observation in institutional ethnography. In: Institutional Ethnography as Practice, D. Smith (Ed), pp. 45-63, Rowman \& Littlefield Publishers, Inc., ISBN 917-0-7425-4676-9, Lanham, Maryland

Ellingson, L. L. (2006). Embodied knowledge: Writing researchers' bodies into qualitative health research. Qualitative Health Research, Vol. 16, No.2, pp. 298-310, ISSN 10497323

Ellis, C. (2002). Being real: moving inward toward social change. International Journal of Qualitative Studies in Education, Vol. 15, No. 4, pp. 399-406, ISSN 09518398

Ellis, C. (2004). The ethnographic I: A methodological novel about autoethnography, AltaMira Press, ISBN 0-7591-0051-9, Walnut Creek, CA

Ellis, C. \& Bochner, A. (2000). Autoethnography, personal narrative, reflexivity, In Handbook of Qualitative Research (2nd ed.), N.K. Denzin \& Y.S. Lincoln (Eds.), pp. 733-768. Sage Publications, ISBN 0761915125, Thousand Oaks, CA

Enloe, C. (2000). Maneuvers: The international politics of militarizing women's lives, University of California Press, ISBN 0520220706, Berkeley

Enloe, C. (2007). Globalization and militarism: Feminists make the link, Rowman \& Littlefield Publishers, Inc., ISBN 074241126, Lanham, MD

Feinman, I. R. (2000). Citizenship rites: Feminist soldiers $\mathcal{E}$ feminist antimilitarists, New York University Press, ISBN 0814726895, New York 
Freire, P. (2000). Pedagogy of the oppressed: $30^{\text {th }}$ anniversary edition. Continuum, 0-8264-1276-9, New York

Gouthro, P. (2002). What counts? Examining academic values and women's life experiences from a critical feminist perspective. Canadian Journal for the Study of Education, Vol. 16, No. 1, pp. 1-19

Harding, S. (1986). Introduction: Is there a feminist method? In: Feminism and methodology: Social science issues, Harding, S. (Ed.), pp. 1-14, Indiana University Press, ISBN 0253204445, Bloomington

hooks, b. (1994). Teaching to transgress: Education as the practice of freedom, Routledge, ISBN 0415-90808-6, New York

Hornosty, J.M. (2004). Corporate challenges to academic freedom and gender equity. In: Inside corporate $U$ : Women in the academy speak out, M. Reimer (Ed.), pp. 43-66, Sumach Press, ISBN 1894549317, Toronto

Kinsman, G. (1995). The textual practices of sexual rule: Sexual policing and gay men. In. Knowledge, experience, and ruling relations: Studies in the social organization of knowledge, Campbell, M., \& Manicom, A. (Eds.), pp. 80-95, University of Toronto Press, ISBN 0802007201, Toronto

Lane, L., Taber, N., \& Woloshyn, V. (in progress). Negotiating tensions between researching, facilitating, and critiquing gender: Exploring institutional and feminist influences.

LePage, P. \& Givens-Generett, G. (2003). Working against the grain: Rewards and consequences of developing a personal voice in academia, In Advancing Women in Leadership, 09.08.2005, Available from http:/ / www.advancingwomen.com/awl/winter2003/LEPAGE 1.html

Motzafi-Haller, P. (1997) Writing birthright: On native anthropologists and the politics of representation, In: Auto/ethnography: Rewriting the self and the social, D. ReedDanahay (Ed.), pp. 195-222, Berg, ISBN 9781859739754, Oxford

Pillow, W. (2003). Confession, catharsis, or cure? Rethinking the uses of reflexivity as methodological power in qualitative research, Qualitative Studies in Education, Vol. 16, No. 2, pp. 175-196, ISSN 09518398

Possick, C. (2009). Reflexive positioning in a politically sensitive situation: Dealing with the threats of researching the West Bank settler experience, Qualitative Inquiry, Vol. 15, No. 5, pp. 859-875, ISSN 10778004

Ramazanoglu, C. \& Holland, J. (2002). Feminist methodology: Challenges and choices, Sage Publications, ISBN 0761951237, Thousand Oaks

Reed-Danahay, D. (Ed.). (1997a). Auto/ethnography: Rewriting the self and the social, Berg, ISBN 9781859739754, Oxford

Reed-Danahay, D. (1997b). Introduction. In: Auto/ethnography: Rewriting the self and the social, D. Reed-Danahay (Ed.), pp. 1-17, Berg, ISBN 9781859739754, Oxford

Reed-Danahay, D. (2002). Turning points and textual strategies in ethnographic writing, International Journal of Qualitative Studies in Education, Vol. 15, No. 4, pp. 421-425, ISSN 09518398 
Reich, J. (2003). Pregnant with possibility: Reflections on embodiment, access, and inclusion in field research, Qualitative Sociology, Vol. 26, No. 3, pp. 351-367, ISSN 13207881

Reimer, M. (Ed.). (2004). Inside corporate U: Women in the academy speak out, Sumach Press, ISBN 1894549317, Toronto

Smith, D. E. (1986). Women's perspective as a radical critique of sociology. In: Feminism and methodology: Social science issues, Harding, S. (Ed.), pp. 84-96, Indiana University Press, ISBN 0253204445, Bloomington

Smith, D. E. (1987). The everyday world as problematic: A feminist sociology, Northeastern University Press, ISBN 1555530362, Boston, MA.

Smith, D. E. (1999). Writing the social: Critique, theory, and investigations, University of Toronto Press, ISBN 0802081355, Toronto.

Smith, D. E. (2005). Institutional ethnography: A sociology for people, AltaMira Press, ISBN 0759105022, Lanham, MD

Taber, N. (2005). Learning how to be a woman in the Canadian Forces/unlearning it through feminism: An autoethnography of my learning journey, Studies in Continuing Education, Vol. 27, No. 3, pp. 289-301, ISSN 0158037X

Taber, N. (2007). Ruling relations, warring, and mothering: Writing the social from the everyday life of a military mother. Unpublished PhD dissertation. Adelaide: University of South Australia.

Taber, N. (2010). Institutional ethnography, autoethnography, and narrative: An argument for incorporating multiple methodologies, Qualitative Research, Vol. 10, No. 1, pp. 525, ISSN 14687941

Taber, N. (2011a). Critiquing war in the classroom: Problematizing the normalization of gendered militarism. Proceedings (S. Carpenter, S. Dossa, \& B. Osborne) of Canadian Association for Studies in Adult Education (CASAE)/Adult Education Research Conference (AERC), 2011 Joint Conference. Toronto: Ontario Institute for the Study of Education, University of Toronto.

Taber, N. (2011b). Ruling relations, warring, and mothering: Writing the social from the everyday life of a military mother, Lambert Academic Publishing, ISBN 3838349083, Saarbrucken, Germany

Taber, N. (2011c). "You better not get pregnant while you're here": Tensions between masculinities and femininities in military communities of practice, International Journal of Lifelong Education, Vol. 30, No. 3, pp. 331-348, ISSN 02601370

Taber, N., Howard, L. \& Watson, G. C. (2010). Researcher subjectivities as a conceptual frame in collaborative research: How exploring the experiences of adult educators led to examining researcher lenses, Canadian Journal for the Study of Adult Education, Vol. 23, No. 1, pp. 39-54, ISSN 0835-4944

Walford, G. (2004). Finding the limits: Autoethnography and being an Oxford University Proctor. Qualitative Research, Vol. 4, No. 3, pp. 403-417, ISSN 14687941

Walker, G. (1995). Violence and the relations of ruling: Lessons from the battered women's movement. In: Knowledge, experience, and ruling relations: Studies in the social organization of knowledge, Campbell, M., \& Manicom, A. (Eds.), pp. 65-79, University of Toronto Press, ISBN 0802007201, Toronto 
Webber, M. (2008). Miss Congeniality meets the new managerialism: Feminism, contingent labour, and the new university. Canadian Journal of Higher Education, Vol. 38, No. 3, pp. 37-56, ISSN 03161218

Woodward, K. (2008). Hanging out and hanging about: Insider/outsider research in the sport of boxing. Ethnography, Vol. 9, No. 4, pp. 536-561, ISSN 14661381 


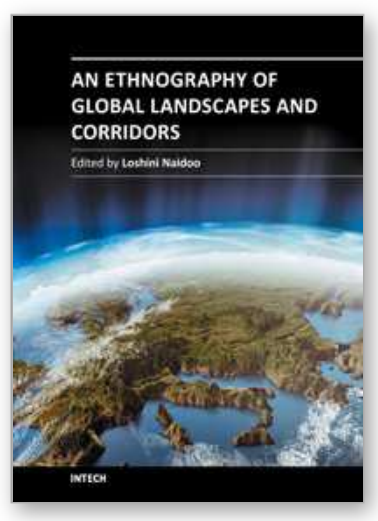

\author{
An Ethnography of Global Landscapes and Corridors \\ Edited by Dr. Loshini Naidoo
}

ISBN 978-953-51-0254-0

Hard cover, 270 pages

Publisher InTech

Published online 09, March, 2012

Published in print edition March, 2012

The chapters presented in this book draw on ethnography as a methodology in a variety of disciplines, including education, management, design, marketing, ecology and scientific contexts, illustrating the value of a qualitative approach to research design. The chapters discuss the use of traditional ethnographic methods, such as immersion, observation and interview, as well as innovative ethnographical methods which have been influenced by the new digital culture. The latter challenges notions of identity, field and traditional culture such that people are able to represent themselves in the research process rather than be represented. New approaches to ethnography also examine the use and implication of images in representation as well as critically examining the role and impact of the researcher in the process.

\title{
How to reference
}

In order to correctly reference this scholarly work, feel free to copy and paste the following:

Nancy Taber (2012). Beginning with the Self to Critique the Social: Critical Researchers as Whole Beings, An Ethnography of Global Landscapes and Corridors, Dr. Loshini Naidoo (Ed.), ISBN: 978-953-51-0254-0, InTech, Available from: http://www.intechopen.com/books/an-ethnography-of-global-landscapes-andcorridors/beginning-with-the-self-to-critique-the-social-critical-researchers-as-whole-beings

\section{INTECH}

open science | open minds

\section{InTech Europe}

University Campus STeP Ri

Slavka Krautzeka 83/A

51000 Rijeka, Croatia

Phone: +385 (51) 770447

Fax: +385 (51) 686166

www.intechopen.com

\section{InTech China}

Unit 405, Office Block, Hotel Equatorial Shanghai

No.65, Yan An Road (West), Shanghai, 200040, China

中国上海市延安西路65号上海国际贵都大饭店办公楼 405 单元

Phone: $+86-21-62489820$

Fax: +86-21-62489821 
(C) 2012 The Author(s). Licensee IntechOpen. This is an open access article distributed under the terms of the Creative Commons Attribution 3.0 License, which permits unrestricted use, distribution, and reproduction in any medium, provided the original work is properly cited. 